\title{
TEAK SECOND ROTATION ESTABLISHMENT EXPERIMENT IN DRY ZONE OF SRI LANKA
}

\author{
K M A Bandara \\ Research Officer, Forestry Department \\ Passara Road, Badulla.
}

Teak (Tectona grandis) is a tree species which grows well in the dry zone of Sri Lanka. During 1960s and 70s nearly 40,000 hectares have been planted with this species as commercial plantations in nutrients rich burnt soil in the low country intermediate and dry zone areas. Most of the established plantations are now in a stage to do the final felling. The micro environmental conditions of the plantations has changed due to different environmental changes such as frequent fire, nutrient removal by harvesting etc. Therefore the second rotation establishment of the same species seem to be a problem.

A field experiment on the second rotation establishment was carried out at Timbolkettiya, Embilipitiya in 1995. Two different propagule types, three different land preparation methods and four different fertilizer applications were applied in a split split plot design.

The propagule type potted stumps $(\mathrm{p}>0.05)$ were far superior to the normal bare rooted stumps in terms of survival percentage and plant's initial growth after the second monsoon rains. In general deep soil loosening (45 $\mathrm{cm}$ hole) had the highest survival $(81 \%)$ and the fastest plant growth $(95 \mathrm{~cm})$ compared to the standard $30 \mathrm{~cm}$ hole $(58 \%$ survival and 72 $\mathrm{cm}$ height). A significant difference $(\mathrm{p}>0.05)$ was not observed between different inorganic fertilizer levels. This could have been due to the adverse environmental conditions which prevailed during the experimental period. The survival for potted plants was $86 \%$ while it was only $42 \%$ for bare rooted stumps. Further, the potted plants reached $95 \mathrm{~cm}$ height compared to $72 \mathrm{~cm}$ for stumps.

Proceedings of the Third Annual Forestry Symposium 1997, of the Department of Forestry and Environmental Science, University of Sri Jayewardenepura, Sri Lanka 